\title{
Destigmatizing The Name Or Moving Up In The Caste Ladder: Family Name Changes Among The Sinhalese
}

\author{
M.W. Amarasiri De Silva And Shantha Wanninayake \\ Department of sociology, Faculty of Arts, University of Peradeniya. \\ DOI: 10.29322/IJSRP.11.02.2021.p11042 \\ http://dx.doi.org/10.29322/IJSRP.11.02.2021.p11042
}

\begin{abstract}
Notifications of name changes published in Sinhala newspapers during 1993 to 1995 , and in1976 were analyzed to see patterns of family name changes and changes of caste status associated with assumption of new family names. Altogether 12547 notifications of name changes were reported during this period. The analysis showed that $71 \%$ of the notifications were about changing family names. $36 \%$ of the notifications of family name changes were about changing family names of the whole family to assume high caste status, while individuals assuming high caste/class family names notified $64 \%$ of family name changes, both by the individuals and the families, $76 \%$ have assumed high cast names, $16 \%$ changed to a caste names, and the rest were change of family names within their own castes. The paper argues that the assumption of high cast names by the 'low castes' does not necessarily lead to changing of caste status to high caste. Such an argument can be a valid one only in the case of name changes notified by the whole family assuming high caste status, which is about $26 \%$ of the total notifications. Any family name changes, $(74 \%)$ were notified by individuals who liked to be called by a name that is non- derogatory, pleasant and prestigious. Which enables better face-to-face relationships, facilitates communication and dealing in the wider society. Thus, individual personal names are loosing their traditional strength as a identifier of caste, family and village of residence among the "low a person has assumed a new role as a marker of class and prestige than an identifier of caste-a phenomenon present among the Sinhalese than in any other ethnic group in Sri Lanka.
\end{abstract}

\section{INTRODUCTION}

$\mathrm{L}$ iterature depicts caste as an ascribed status, which is for life and not amenable to change. However, in recent times, owing to many factors and forces of change, the nature of caste has also changed. It is well known that caste plays an important role in social and political life of Sinhalese. Many traditional attributes of caste, such as form of address and dress had disappeared by 1950s, and by then, an individual's caste, could have been identified by his/her name, residence and occupation (Yalman, 1961). This paper shows that, in the present times, personal and family names have been subject to a process of change, in which the traditional role of personal and family names as caste identifiers has become obsolete. Individual personal names have assumed a new role as a marker of class than an identifier of caste.

Changing names by notifying in newspapers has been practiced for several decades. The name changes notified in newspapers were two types. The personal or first names, and the family names. The focus of this paper is on family name changes, particularly those that imply change in caste status. The family names are of several types. Family names in the traditional period distinguished between patabendi (honorific) names and nonpatabendi names. Traditionally patabendi names were conferred for conspicuous military exploits by the kings (Pieris, 1956). During the times of Kandyan kingdom, patabendi names were found in dominant, radala Goigama families who were landed aristocracy. The patabendi names were later treated as patronymics and used as surname by the descendant of the conferee. "Scions of a man honoured with a patabendi title such as Suriyasekara Mudiyanse would convert it into a patronymic and call themselves Suriyasekara Mudiyanselage, 'descendants from Suriyasekara Mudiyanse' (Pieris, 1956). Referring to this process of adopting patabendi titles in the form of honorific and patronymics Obesekere concludes that it 'has resulted in a spread of patabendi titles in Kandyan society' (Obesekere, 1967). Science such patronymics are widly used by affluent families in the Kandyan provinces, who were by and large Goigama, the patronymics were generally thought of as a prerogative of the Goigama caste, particularly Goigamaradala.

Although we do not have sufficient information about patabendi names being used by castes other than the Goigama during or prior to the Kandyan era, different caste have folk stories reffering to conferring of honorific names upon their ancestors by the Kings and provincial rulers. Conferrings of patabendi names was evident during the time of colonial rulers, who upon appointment of local regional official, granted patabendi names to the incumbants of these new offices. Obeysekere however states that "with the three streams of foreign conquest, the prohibition against assuming patronymics and title associated with rank was lifted,and there was a mass 'usurpation' of these honorifics particularly among the dominant Goigama and a few of the karawa castes' (Obeysekere, 1967). Presence or absence of a patabendi name puts a label on the person as to his/her caste status and class status within the caste., hierarchy than those who had a patabendi name. thepatabendi name as has been used lately were indicative of the distinction between upcountry and low country, and sometimes distinctions associated with religious affiliations.

The next most important category of name is known as the vasagama names. During the Kandyan period, ordinary Goigama peoples who did not use patabendi names had vasagama names. The vasagama name, as implied, indicates the hamlet or village where the incumbent of the particular vasagama name resided or originated. As each hamlet or village comprises several kin geoups, as clearly started by Obeysekere, vasagamanemes usually 
have name suffixes to identify the particular line of succession. For example, the name Pahala Medagamagamage Jinadasa, mentioned in Obeysekere (1967), has three distinct aspects of a name with a vasagama. The first two words 'Pahala Medagama' refers to the hamlet or village of origin or vasagama of Jinadasa. Jinadasa is his personal name. Jinadasa of pahala Medagama belongs to the particular line of succession named 'gamage'. Thus, the vasagama entails the name of the hamlet of residence, his line of succession, and his personal name.

The people without patabendi or vasagama names were the low caste in the Kandyan Kingdom. While some of these people were identified with a Ge name (house name) such as Ihala Gedara or Pahala Gedar, some others were identified with their father's name. E.g: Ukkuwage Puncha (Puncha, the son of Ukkuwa). Yalman observed that ordinary Goigama people, as opposed to the aristocratic Goigama, were considered 'low' in caste status because their forefathers had been serfs and did not have prolific title names. 'These serfs were no longer bound by feudal (rajakariya) laws but 'respectable' people would not intermarry or interdine with them. Their 'lowness' was evident in their names, for they were distinguished from other Goigama-so it was claimed- by there lack of ancient titles and vasagama names. They had been the 'working people' (vadakarayo) like the low castes'(Yalman, 1961).

Although the traditional naming system had important symbolic identity and meaning required for stratification and interaction in traditional villages, in the changed social system of modern times, the social identity denoted in names does not necessarily correspond to the assumed social roles and status of the people. While the traditional Ge (house or family) names and personal names, particularly of those that are considered to be 'low castes', are now regarded as a barrier for socialization of people in the changing societies, the vasagamas, honorific and patronymics of the high castes being emulated and used to pejoration have lost their traditional social vitality of demonstrated leadership and proprietorship. In traditional villages however, the potter or the washerwomen was identified by the particular family $(\mathrm{Ge})$ and persona name, which was one of the ways of segregating people of different castes, ans putting them in social positions relative to the higher castes in the villages. Although the 'low castes' people may not have liked the way that they have been identified and labeled as being people without vasagama and honorific, they could not do anything to prevent the continuity of such a system for the naming system was regulated by the high caste people. The registrar of birth and deaths, who registered the name of the new born children, and who was often a Goigama caste person in the up country villages, had the discretion to christen the children of low caste parents according to the traditional system of naming. Even when the parents wanted to name their children differently to alleviate the social stigma attached to names given to their caste, the registrars did not go against the tradition, even though caste of an individual has become less of a status marker in the present day Sri Lankan society, the traditional naming system that prevailed until recently and still found in villages, continued in many different ways to foster the caste hierarchy and perpetuate the stigma attached to 'low castes'. Name changes are one of the necessary and accepted forms of eliminating the lingering notion of 'caste- related lowness' of a person in modern society, though it is not a 'sufficient condition' for upward mobility of a person.
Prior to newspaper advertisements became an accepted form of changing family names, the problem of 'lowness' of names and changing such low-status names to high-status names was faced by people in traditional society. Low caste, but powerful persons who aspire to assume social prestige practiced hypogamy or marrying up from a higher caste was one such strategy found in the traditional society. Yalman (1961) described how an ordinary Goigama person named Dehi Gaha Pitiya Kalu Banda Terutenna, who did not have a vasagama name, had assumed his wife's aristocratic (radala) name Nissanka Mudiyanselage Tun Amunu Gedara. Dehe Gaha Pitiya Kalubanda of Terutenna was lucky to be able to rescue a Eiuropean Official from an attack by a wild elephant, which resulted in succeeding him to the post of village headman. Kalu Banda married from an aristocratic family and began to use the aristocratic title of his wife Nissanka Mudiyanselage Tun Amunu Gedara, which was assumed by almost all the kinsmen of Kalu Banda. Yalman (1961) also says 'we may note that there were some 'low' Goigama who had grown rich and thereupon changed their place of residence and successfully assumed aristocratic titles'. (Yalman, 1961, p88). Another mechanism of assuming title names (honorifics and patronymics) reported by Obeysekere (1967) in Hinidumpattuwa shows how the rich and the powerful who emancipated from the ordinary caste and kin groups had formed new social bonds with similar powerful rich families of the same caste in the region. In Hinidumpattuwa, these groups were referred to as pelantiva, who became distinct from the ordinary caste members, by their distinct honorifics and patronymics, which often resembled title names (patabendinam) bestowed upon by the kings in the Kandyan Kingdom.

Name changes as appeared in Sinhala newspapers have escalated in numbers during the last decade. The increase was so dramatic that in 1976, just before the economic liberalization policies were introduced, only 484 people notified changes of their names in newspapers, but after two decades in 1993, 1994, and 1995 the numbers increased to more than 3000 per year, and it is on the increase ever since as shown in Figure 1. In this context it is pertinent to ask why do people change their names? As observed by Obesekere (1967) is it true to say that 'usurpation of honorifics... is an emulation of a position of power, prestige and authority by persons who were traditionally debarred from such positions. Is it because people want to do away with names that reflect the associated caste status? Or is it because that the traditional naming system has become obsolete and it is given a new meaning in the modern class society?

This paper attempts to answer some of these questions in the context of class and caste mobility of individuals among the Sinhalese.

\section{METHODOLOGY}

Data for study were obtained from newspaper notifications of name changes which appeared in Sinhala news papers during 1993 to 1995 . The data were compared with notifications published during 1976, just before the economic liberalization policies were introduced, to gauge the numerical increase of notifications of name changes. The data were extracted using a data collection guide that was developed after reading some of the 
notifications. The areas specified in the guide for collection of data were.

1. Type of name change (first name or the family name)

2. By whom (individual or family)

3. If an individual has changed the name was he/she a male or a female

4. Names used by families and individuals prior to change

5. Caste indicated in the previous (old) name

6. The assumed name (new) and the caste indicated in the assumed name

7. District of residence

8. The date of notification.

The castes associated with names were identified through discussion with key-informants from geographical areas. The data were computer analyzed to see the distribution of names by caste, district and gender before and after the assumption of new names.

\section{RESULTS}

Altogether 12063 notifications of name changes were published in Sinhala news papers during the three years of 1993 to 1995, giving and average of 4016 notifications per year. The notifications pubished in 1976 were 484 which was about mine times less than the average notifications published by any year from 1993 to 1995. The tremendous increase in the number of notifications in recent years indicates the significance of name changes as a form of individual and class mobility, and a mechanism of destigmatizing one's family name. In addition, it shows that names have increasingly been recognized as markers of social status of an individuals in the wider society.

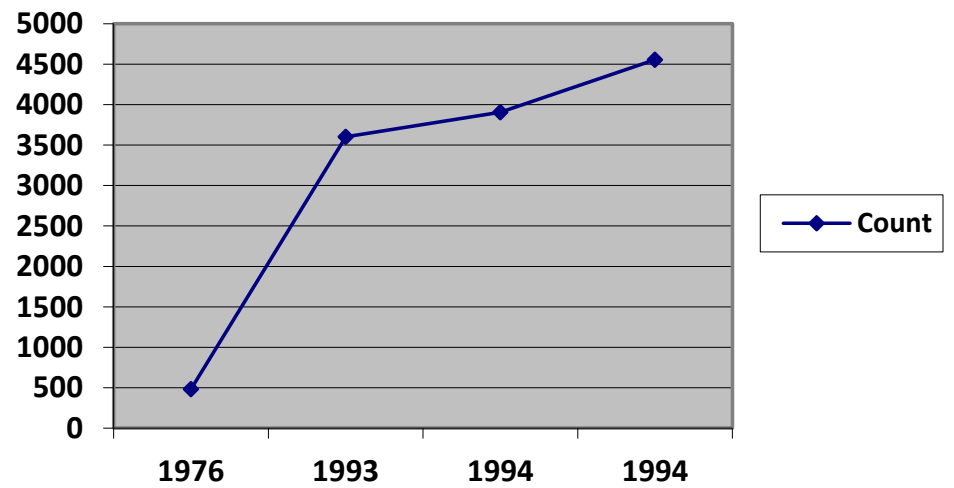

Fig. 1. Number of family name changes reported in the news paper from 1976 to 1995

Of the total 12547 notifications, $28.4 \%$ were about changes of first (personal) names, $25.7 \%$ were about changes of family names by whole family, and the rest were about individuals changing their family names $(19.5 \%)$ or family names and first names $(26.4 \%)$. The notifications on family name changes have increased from $20 \%$ in 1976 to $34 \%$ in 1993-1995. On the contrary, changes of personal (first) names have gradually dropped from $30 \%$ in 1976 to $27 \%$ in 1995 . The decrease in changes of personal names might have been due to registration of births at the hospitals, where $85 \%$ of total births occur, which allows greater freedom for the parents to name their children as they wish. However, assumption of new family names required going through the legal procedures involving notifying in newspapers, which has assumed a considerable increase over the years (Figure 1). The percentage distribution of family name changes does not vary across years.

If assumption of new family names were about assuming an entirely new caste status then about $75 \%$ of those who assumed new family names have changed their caste status from a ' low cast' to the Goigama or radala Goigama. If this is an acceptable hypothesis, at the present rate of conversion, the average number of families assuming Goigama caste status amounts to about 1000 (or approximately 5000 persons) every years. In addition, there are about 2000 individuals assuming Goigama caste names each year. This is a phenomenal contribution to the increase of the Goigama caste in the country in number and strength, irrespective of the fact that the traditional values attached to patronymics, honorific and vasagama names of the Goigama being 'pejorated' as observed by Obeyesekere(1967).

The individuals who have changed their family names were predominantly males (about 70\%). Though the authors do not have information on their age and relative social status, The authors inclined to think that those individuals who opted to change their names were the youth who were aspiring to move up the social ladder through employment and contracting marriage.

\section{Table I. Family name changes by districts}

\begin{tabular}{|lllll|} 
District & $\begin{array}{l}\text { Frequenc } \\
\mathbf{y}\end{array}$ & $\begin{array}{l}\text { percen } \\
\mathbf{t}\end{array}$ & $\begin{array}{l}\text { Valid } \\
\text { percen } \\
\text { t }\end{array}$ & $\begin{array}{l}\text { Cumulativ } \\
\text { e percent }\end{array}$ \\
\hline Colombo & 1193 & 13.3 & 14.0 & 14.0 \\
\hline Kurunegala & 1092 & 12.2 & 12.8 & 26.7 \\
\hline Gampaha & 1079 & 12.1 & 12.6 & 39.3 \\
\hline Kandy & 775 & 8.7 & 9.1 & 48.4 \\
\hline Rathnapura & 754 & 8.4 & 8.8 & 57.2 \\
\hline Kegalle & 714 & 8.0 & 8.3 & 65.6 \\
\hline $\begin{array}{l}\text { Anuradhapur } \\
\text { a }\end{array}$ & 508 & 5.7 & 5.9 & 71.5 \\
\hline Badulla & 449 & 5.0 & 5.3 & 76.8 \\
\hline Matara & 316 & 3.5 & 3.7 & 80.5 \\
\hline Galle & 290 & 3.2 & 3.4 & 83.8 \\
\hline Kaluthara & 280 & 3.1 & 3.3 & 87.1 \\
\hline Matale & 256 & 2.9 & 3.0 & 90.1 \\
\hline Puttalam & 204 & 2.3 & 2.4 & 92.5 \\
\hline Hambantota & 180 & 2.0 & 2.1 & 94.6 \\
\hline Nuwaraeliya & 132 & 1.5 & 1.5 & 96.2 \\
\hline Polonnaruwa & 125 & 1.4 & 1.5 & 97.6 \\
\hline Monaragale & 119 & 1.3 & 1.4 & 99.0 \\
\hline Ampara & 60 & 0.7 & 0.7 & 99.7 \\
\hline Trinco & 16 & 0.2 & 0.2 & 99.9 \\
\hline Vavuniya & 7 & 0.1 & 0.1 & 100.0 \\
\hline Jaffna & 2 & 0.0 & 0.0 & 100 \\
\hline
\end{tabular}




\begin{tabular}{|llll|}
\hline Total & 8551 & 95.6 & 100.0 \\
\hline $\begin{array}{l}\text { System } \\
\text { missing }\end{array}$ & 395 & 4.4 & \\
\hline Total & 8946 & 100.0 & \\
\hline
\end{tabular}

As seen in any social context of Sri lanka, those aspiring to change are the males in their prime youth. However, the percentage of females assuming family name changes have increased from $22.5 \%$ in 1976 to $33.3 \%$ in 1995 , showing that females of non-Goigama caste are increasingly becoming socially mobile and aspiring to change their social status. This may be a sign of improvement in the quality of life of 'low caste' women, who were traditionally poor and less educated.

The distribution of family name changes notified by individuals and families, as shown in Table I, indicates that the higher percentages were found in 'urban' districts such as Colombo, Gampaha and those district that are found in the traditional Kandyan territories. Urban district of Colombo and Gampaha accounted for about $25 \%$ of family name changes, while the district that formed part of the Kandyan territories, such as Kurunegala, Kandy, Rathnapura, Kegalle, Anuradhapura and Badulla accounts for another $50 \%$ of family name changes. The district on the littoral though very populous, has reported relatively few notifications on family name changes. The districts with a large percentage of Tamil populations, such as Vauniya, Jaffna, and Trincomalee, reported only a few notifications. Some districts like baticalloa and mannar did not report any notifications, indicating that among the Tamil and Muslims, family name does not seem to have a particular social prestige or caste connotations attached to it. It may be possible that such notifications are published in Tamil news papers. It is worth mentioning that there were $6.5 \%$ notifications by Tamils who sought Sinhala family names of Goigama caste. The majority of them were from Colombo (28\%), while Rathnapura (11\%), Gampaha (9\%), Kaluthara (8\%) and Kandy $(8 \%)$ reported a fairly high percentage of Tamils seeking Sinhala Goigama names. $85 \%$ of all Tamils seeking name changes have published their notifications during 1994 to 1995.

\section{Patterns of Family Name Changes}

Title names,(honorific and patronymics), vasagama names and $G e$ names are all treated as family names for the convenience of analysis. Of all family name changes, $28 \%$ were by Goigama people. Of the Goigama people who opted for a change in their family name, $50 \%$ were males, $45 \%$ were females and about $5 \%$ were whole families. The newly assumed names by the Goigama, as indicated in the notifications, were basically of two types. First, modernization of family names by rearranging them in the English/Western style of presenting names. Second assumption of traditional title names and honorifics.

(a) Yapa Mudiyanselage Yhapath Hami was changed to Yapa Mudiyanselage Rnjith Priyantha Yapa. Here the name has assumed a high-class status and it is modernized. Adding the traditional vasagama name as a suffix is a modern way of making the names look elegant. When the name is written with initials, then the traditional family name "Yapa" can be shown in the name. E.g. Y.M.R.P. Yapa. This will bring the family name or the kingship line to the forefront. If the old name were written in the same way, it would be Y.M.R.P. Yapa is quite distinct.

(b) Udagama Liyange Alice Noona has been changed to Udagama Liyanage Ashoka Udagama or U.L.A. Udagama. Here the change of personal name is not obvious as it is written with initials. (Which is a practice adopted by the 'low castes' in their name changes, which will be discussed later) the way most Sinhalees nowadays write their names.

(c) P.M. SarlisAppuhami, from Colombo, has changed his name to Charles Sirigunatileke. Here the first name has been modernized and the traditional Appuhami name has been dropped. A colorful modern caste name has been adopted.

(d) Dan Watta Liyanage Kmalawathi has been changed to Illeperumage Dona Kamalawathi Ariya Wijenayake. The family name Liyanage is a Goigama sub caste name found in the low country. The assumed name of Wijenayake connotes high caste and high class ststus. When Kamalawathi is changed in to Dona Kamalawathi, it makes a big change from an ordinary first name to a low country aristocratic first name.

(e) Jayawardene Mudalige Arumawathie is changed to Jayawardene Mudalige Aruna Jayawardene. Here the traditional name has been modernized by using part of the vasagama name as a suffix. The two names when written with initials look different and portray two different social statuses. J.M Arumawathie is very much of a village name, while JMA Jayawardene looks elitist.

(f) K.H. Heen Banda has been changed to sumith Attanayake. Here an ordinary Goigama name has been changed to a modern Goigama name. Tis person being a resident in Colombo preferred Sumith to Heen Banda, with a colorful family name Attanayake. Incidentally, Attanayake was the name under which Rohana Wijeweera sought refuge during his last few years of underworld politics.

(g) Ukku Bandage Ran Banda of Anuradhapura had changed his name Wanninayake Mudiyanselage Ranjith bandara Wanninayake. As pointed out by Leach, most village in Anuradhapura do not have vasagama names. Although they are Goigama, they do not have titles or prestigious vasagama. They follow the tradition of using father's name as an identifier of the son as in the case of Ukku Bandage Ram Banda (Ram Banda, the son of Ukku Banda). Many name change of ordinary goigama in Anuradhapura district are of this type.

Sometimes, especially when a child is born to an unmarried womwn, the name is given after the mother. Kiri Menikage Karunadasa is such an example. This name was changed to a title name with suffix of Mudiyanse.

(h) Wijethunga Mudiyanselage Sarath Bandara or W.M Sarath Bandara has been changed to Sarath Bandara Wijethunga or S.B Wijethunga. This is an ideal example of modernization of names by the Goigama, where the family names has assumed only part of the traditional title name. in this change, it is clear that S.B Wijethunge assumed higher social status than W.M Sarath Bandara. 
Table II. Percentage distribution of non -Goigama castes who changed their family name*

\begin{tabular}{|lll|}
\hline Castes & Valid percent & $\begin{array}{l}\text { Cumulative } \\
\text { percent }\end{array}$ \\
\hline Bathgama & 17.4 & 17.4 \\
\hline Naketi & 17.1 & 34.5 \\
\hline Dura & 13.7 & 48.3 \\
\hline Hena & 13.1 & 61.6 \\
\hline Wahumpura & 10.9 & 72.6 \\
\hline Acaste & 10.6 & 83.2 \\
\hline Achari & 6.7 & 89.9 \\
\hline Karawa & 4.3 & 94.3 \\
\hline Kumbai & 2.0 & 96.3 \\
\hline Salagama & 1.5 & 97.8 \\
\hline Patti & 0.8 & 98.6 \\
\hline Durawa & 0.7 & 99.3 \\
\hline Panna & 0.2 & 99.5 \\
\hline Gattara & 0.2 & 99.7 \\
\hline Rodi & 1.0 & 99.9 \\
\hline Galladu & 1.0 & 99.9 \\
\hline Hunu & 1.0 & 100.0 \\
\hline Total & 100.0 & \\
\hline
\end{tabular}

* Family name that do not indicate caste identity

Table III. Distribution of the assumed caste status

\begin{tabular}{|lll|}
\hline Castes & Valid percent & $\begin{array}{l}\text { Cumulative } \\
\text { percent }\end{array}$ \\
\hline Goigama & 74.1 & 74.1 \\
\hline Acaste & 15.1 & 89.2 \\
\hline Karawa & 4.6 & 93.8 \\
\hline Bathgama & 0.9 & 94.7 \\
\hline Hena & 0.9 & 95.7 \\
\hline Hakuru & 0.8 & 96.5 \\
\hline Nakati & 0.7 & 97.2 \\
\hline Dura & 0.6 & 97.8 \\
\hline Durawa & 0.6 & 98.4 \\
\hline Kammal & 0.6 & 99.0 \\
\hline Salagama & 0.4 & 99.4 \\
\hline Goi-radala & 2 & 99.6 \\
\hline Achari & 0.1 & 99.8 \\
\hline Patti & 1 & 99.6 \\
\hline Kumbal & 0.1 & 100.0 \\
\hline Galladu & 0 & 100.0 \\
\hline Total & 100.0 & \\
\hline
\end{tabular}

Family name changes among the non-Goigama castes are the most striking of the total number of people who changed their names, 64\% were from non-Goigama castes. As shown in Table II, of those who sought name changes, Bathgama, Nekethi, Dura, Hena and Wahumpura were the numerically important castes. Bathgama and Dura which were traditionally concentrated in Kandyan districts are now dispersed in other districts as well, as revealed in the notifications. (Table IV). Bathgama person living in districts outside the traditional Kandyan territories who changed their family names amounted to $40 \%$ of the total Bathgama person who changed their family names, while it was about $12 \%$ for Dura caste. This shows that the Bathgama castes has been mare dynamic than the Dura, and has moved outside their traditional villages during the last several decates. It is interesting that those Dura and Bathgama residents in the low country district have assumed some low country family names of the Goigama, Karawa and Salagama. For example, in Galle district, about $13 \%$ of dura cast persons have assumed Karawa (9\%) and salagama (4\%) names.

Name changes by the 'low caste' persons seem to display a pattern that is obviously different from that of the Goigama who changed their names. The most widely seen practice among the 'low caste' is de-stigmatizing the derogatory family names by assuming new family names that are similar to ad resembling those of the Goigama caste. Assuming new ge names and omitting traditional family names connoting caste status is a trend in family name changes among the 'low caste'. The new Genames resemble Goigama family names, although they are not traditional Goigama family names. This type of inventing family names without caste connotations can be seen in many name changes were reported in the notifications. Such new family names are identified in this study as a caste names. 
Table IV. Distribution of Non- Goigama caste seeking family name changes by district of residence

\begin{tabular}{|c|c|c|c|c|c|c|c|c|c|c|c|c|c|}
\hline & \multirow{2}{*}{ Neketi } & \multirow[b]{2}{*}{$\begin{array}{c}\text { Kum } \\
\text { bal }\end{array}$} & \multirow[b]{2}{*}{$\begin{array}{c}\text { Salagam } \\
\text { a }\end{array}$} & \multirow[b]{2}{*}{ Hena } & \multirow[b]{2}{*}{ Patti } & \multirow[b]{2}{*}{$\begin{array}{c}\text { Bathgam } \\
\text { a }\end{array}$} & \multirow[b]{2}{*}{$\begin{array}{c}\text { Karaw } \\
\text { a }\end{array}$} & \multirow[b]{2}{*}{$\begin{array}{c}\text { Wahumpur } \\
\text { a }\end{array}$} & \multirow[b]{2}{*}{$\begin{array}{c}\text { Duraw } \\
\mathrm{a}\end{array}$} & \multirow[b]{2}{*}{ Dura } & \multirow[b]{2}{*}{ Achari } & \multirow[b]{2}{*}{ Acaste } & \multirow[t]{2}{*}{ Total } \\
\hline & & & & & & & & & & & & & \\
\hline Trinco & $0.4 \%$ & & & & & $0.4 \%$ & & & & & & $0.7 \%$ & $0.2 \%$ \\
\hline Ratnapura & $9.4 \%$ & $\begin{array}{r}56.0 \\
\%\end{array}$ & $19.0 \%$ & $22.9 \%$ & & $10.0 \%$ & $3.4 \%$ & $24.0 \%$ & $11.1 \%$ & $9.2 \%$ & $28.7 \%$ & $13.2 \%$ & $15.2 \%$ \\
\hline Puttalam & & & $4.8 \%$ & $1.1 \%$ & & $2.2 \%$ & $1.7 \%$ & $0.7 \%$ & & $0.5 \%$ & $3.4 \%$ & & $1.1 \%$ \\
\hline Polonnaruwa & $1.3 \%$ & $4.0 \%$ & & $0.6 \%$ & & $2.6 \%$ & & $2.1 \%$ & & $1.6 \%$ & & $2.8 \%$ & $1.6 \%$ \\
\hline Nuwaraeliya & $4.7 \%$ & & $4.8 \%$ & $0.6 \%$ & & $1.7 \%$ & $1.7 \%$ & $1.4 \%$ & $11.1 \%$ & $2.7 \%$ & $1.1 \%$ & $3.5 \%$ & $2.4 \%$ \\
\hline Moneragala & $7.7 \%$ & & $19.0 \%$ & & & $0.9 \%$ & & $4.1 \%$ & & $1.1 \%$ & & $5.6 \%$ & $3.0 \%$ \\
\hline Matara & $10.7 \%$ & $4.0 \%$ & $14.3 \%$ & $12.6 \%$ & $18.2 \%$ & $1.3 \%$ & $8.5 \%$ & $2.1 \%$ & $22.2 \%$ & $1.1 \%$ & $9.2 \%$ & $0.7 \%$ & $5.8 \%$ \\
\hline Matale & $6.4 \%$ & & & $2.3 \%$ & & $2.6 \%$ & $1.7 \%$ & $2.1 \%$ & & $4.3 \%$ & $2.3 \%$ & $13.9 \%$ & $4.4 \%$ \\
\hline Kurunegala & $8.5 \%$ & $4.0 \%$ & & $14.3 \%$ & $18.2 \%$ & $10.8 \%$ & $6.8 \%$ & $9.6 \%$ & & $15.2 \%$ & $3.4 \%$ & $1.4 \%$ & $9.5 \%$ \\
\hline Kegalle & $3.8 \%$ & $8.0 \%$ & & $6.9 \%$ & $18.2 \%$ & $16.5 \%$ & $3.4 \%$ & $6.2 \%$ & & $5.9 \%$ & $4.6 \%$ & $7.6 \%$ & $7.5 \%$ \\
\hline Kandy & $9.8 \%$ & & & $9.1 \%$ & $45.5 \%$ & $10.8 \%$ & $5.1 \%$ & $7.5 \%$ & $11.1 \%$ & $11.4 \%$ & $9.2 \%$ & $18.1 \%$ & $10.5 \%$ \\
\hline Kalutara & $0.4 \%$ & $8.0 \%$ & $4.8 \%$ & $3.4 \%$ & & $1.3 \%$ & $3.4 \%$ & $5.5 \%$ & & $0.5 \%$ & $3.4 \%$ & $2.8 \%$ & $2.3 \%$ \\
\hline Hambantota & $3.8 \%$ & & & $1.7 \%$ & & $1.3 \%$ & $3.4 \%$ & $2.1 \%$ & & $1.6 \%$ & $4.6 \%$ & $2.1 \%$ & $2.3 \%$ \\
\hline Gampaha & $1.7 \%$ & & $9.5 \%$ & $6.9 \%$ & & $19.0 \%$ & $8.5 \%$ & $5.5 \%$ & $11.1 \%$ & $1.6 \%$ & $6.9 \%$ & $2.8 \%$ & $6.7 \%$ \\
\hline Galle & $1.7 \%$ & $8.0 \%$ & $14.3 \%$ & $6.3 \%$ & & $0.9 \%$ & $18.6 \%$ & $10.3 \%$ & $22.2 \%$ & $1.6 \%$ & $4.6 \%$ & $1.4 \%$ & $4.4 \%$ \\
\hline Colombo & $5.1 \%$ & $8.0 \%$ & $9.5 \%$ & $8.0 \%$ & & $7.8 \%$ & $20.3 \%$ & $8.2 \%$ & $11.1 \%$ & $3.8 \%$ & $9.2 \%$ & $9.7 \%$ & $7.7 \%$ \\
\hline Badulla & $12.0 \%$ & & & $1.1 \%$ & & $2.2 \%$ & $5.1 \%$ & $7.5 \%$ & & $32.4 \%$ & $3.4 \%$ & $7.6 \%$ & $9.3 \%$ \\
\hline Anuradhapura & $9.8 \%$ & & & $1.7 \%$ & & $6.9 \%$ & $5.1 \%$ & $1.4 \%$ & & $3.8 \%$ & $5.7 \%$ & $4.9 \%$ & $5.0 \%$ \\
\hline Ampara & $2.6 \%$ & & & $0.6 \%$ & & $0.9 \%$ & $3.4 \%$ & & & $0.5 \%$ & & $1.4 \%$ & $1.1 \%$ \\
\hline Total & $\begin{array}{r}100.0 \\
\%\end{array}$ & $\begin{array}{r}100.0 \\
\%\end{array}$ & $100.0 \%$ & $\begin{array}{r}100.0 \\
\%\end{array}$ & $\begin{array}{r}100.0 \\
\%\end{array}$ & $100.0 \%$ & $\begin{array}{r}100.0 \\
\%\end{array}$ & $100.0 \%$ & $\begin{array}{r}100.0 \\
\%\end{array}$ & $\begin{array}{r}100.0 \\
\%\end{array}$ & $\begin{array}{r}100.0 \\
\%\end{array}$ & $\begin{array}{r}100.0 \\
\%\end{array}$ & $\begin{array}{r}100.0 \\
\%\end{array}$ \\
\hline
\end{tabular}

*Those caste that had less than $5 \%$ of caste name changes were omitted from table IV. 
(a) Upasaka Panikkiyalage Somasiri was changed to Udadeniye Pathiranage Somasiri. In the assumed name, Panikkiyalage has been committed for its obvious caste connotation. As in the case of some of the Goigama name changes, here too, retaining the same initials can be seen. U.P Somasiri is retained throughout. The difference between the two names is striking. The first one donates the meaning of 'the son of the pious Panikkiya- the drummer- of Udadeniya', ahile in the second name it means 'of the house of Udadeniyepathirana or 'of Udadeniye Pathirana line of succession'. b) Ranhili Pedige to Ranasinghege. In this example, whole family has changed over to Ranasinghege family name. pedige is usually a well-known traditional family name of the Bathgama caste in some districts. This family has replaced their traditional name to Ranasinghege, which is not a recognized Goigama name indicating line of succession. although many Goigama people, particularly the low country Goigama use Ranasinghe as a prestigious family name, they seldom use it as a name of a particular line of succession such as Gamage.

(b) Assuming new family name that are widely used by the particular caste is another form of changing family name. quite a large number of name changes by the Dura caste persons reported to have assumed Pathiranage, while Rajapakshage, and Nuwarapakshage were some assumed family names preferred by the Bathgama caste persons, which, going by the notifications, seem to be recognized modern family names of the Dura and Bathgama caste.

(c) Rankiralaya Nandoris Alias Wijepala was changed to Rathnayakege Sunil Senanayeke. This new name should have been changed to Rathnayeke Mudiyanselage Sunil Senanayake Rathnayake, or RMSS Rathnayake, to make the changefully effective. However, this person did not do it, may be, for two reasons. Being a person from a traditional village in Rathnapura, he must have thought that his fellow villagers might oppose such a drastic name change. What is expected of this name change was eliminating the traditional name that was indicative of his caste and 'low' rank. Although Rathnayaka is a well-known Goigama name, there is no accepted line of succession called Rathnayakege. It is interesting that this name was not changed to Rathnayaka Mudiyanselage, which is a widely used title name of the Goigama.

(d) Many of the castes 'low castes' have assumed part of their traditional name or changed the wordings of the traditional names to make them prestigious. Examples for this are the following: Weledurayalayegedara Pina was changed to Mangala Gamage Chandrasena Welagedara. Obviously, the omission of durayaleye from the traditional name resulted in the new name of Welagedara, which is a prestigious Kandyan Goigama name. other examples are Welekumburegedara to Welagedara, Hewahakuruge to Hewage, and Bambaranda Badalge to Bambarande.

(e) Complete new assumptions of title names and vasagama names, which have no relationship what so ever to the traditional names, were also found in the notifications. This type of assumptions of names matches hat Obeyesekere has observed as pejoration of Goigama honorifics and patronymics. Examples are the following: Hapan Pedige Pina changed his name to Gemunu Abhayawardene. Hewapedigepalitha changed to Palitha Hewa Pathiran, Suddha Viriduwalage Rampi changed to Subhasinghe Wickramage Ranjani. Miyanadeniya Manannalage Jasoris changed to Miyanadeniye Mudiyanselage Senaratne. Millana Acharige Piyasena changed to Millane Arachchige Piyasena Millane. Hawadi Durage Gunawathi changed to Dissanayake mudiyanselage Chandra Rathnayake. Alutgedara Ukkuamma to Neket Walauve Gedara Seeta Kumarihami. This person has assumed the name of a walauva (manir house) and the personal name Kumarihami, which is traditionally used by radala Goigama, while retaining her traditional Neketi caste name that is nakatgedara. Suduhakuru Nobert changed toa Nobert Wijesinghe and Horatalpedige Allen, a person from Colombo has changed his name to Hrischandra Liyanage Allen Rathnayake, which is a good example for assuming a modernized, upper class Goigama name. suduwa Devage Leslie Tenyson Fernando changed his name to Sirimannage Leslie Tenyson Sirimanne. Here it appears that the name had been changed earlier to look like a Karava name. But the bearer was not statisfied with that social status. Now he has changed it to a high class Goigama name. in another notification, Medawewagedara peiris changed his name to Medawewa Gedara Peiris Nihal Medawewa. This is a fine example to show how people modernize 'low caste to look like high caste aristocratic names, without changing the original $\mathrm{Ge}$ name. here part of the $G e$ name i.e Medawewa is used as a vasagama. Tis new vasagamasounds like a Goigama upper class name. many traditional vasagama name in Anuradhapura area end with a suffix wewa (tank). E.g. Mahadiulwewa. But this person was from Nuwaraeliya where tank irrigation was not much known.

(f) Creation of non-traditional family names that identify the caste, but not derogative as those of the traditional family names. Examples are the following. Wedanchari Neketige was changed over to Weddarachchi Narayanage. Panikka Weerayalage was changed to Peter Wansakkarage. Matara Badalge was changed to Matara Bandarage. These names are obviously non-existent 'Goigama Type' names. Another example is Badahela Badde Vidanayalage Peria Appu, who changed his name to Deva Bandu Kumarathungalage Peris Chandradasa. Here the obvious caste cannotations in the vasagama have been omitted, and Appu has been dropped off, even though it was a popular Goigama name several decades ago. Then new name is acaste, but resembles a classy name. RDP jayalath Nona has changed to Rajapaksege Vinita Rajapakse. This person from Narammala has an obvious caste connotation in here name. However, the new name Vinita, a recent name with a modern outlook, with the changed vasagama from RDP to Rajapaksage makes the name different. Rajapaksage in this particular area is of the same caste as RDP, but they are a modern way of identifying the upper class status within the caste.

(g) In changing family names, one of the features that can be seen, particularly among the 'low caste' is retention of the initials. Retaining the initials or in other words, coining a 
family name to suit the initials would not reveal that the family name has been changed. Following are some examples of this type.

Ethugalpedige piyatilleke to Epa Pathiranage Piyatilleke

Here the name when written with the initials (E.P Piyatilleke) looks the same, and the people would not know that the name has been changed.

Nuwarapaksa Pedige Turin Rathnayake to Nawarathna Pathiranage Turin Rathnayake. In both case, the name is written as NP Turin Rthnayake.

Hewage Charles to Hettiarachchige Charles or HG Charles. Karunapedige Wijerathna to Kumara patirajage Wijeratneor KP Wijeratne.

Kaludevage to Kulasuriyage.

This is a change of vasagama name by a whole family in Kaluthara. Kaludevage has a caste connotation. Kulasuriya is a Karawa middle- class name. the initials $\mathrm{KG}$ are seen in the new name.

Mananalage Gedara Puncha to maha GedaraDharmaratne.

An acaste name.the initials remain the same-MG.

$\underline{\text { Rantilake Pedige Kiri Banda to Rajapaksha Pathirannehelage Kiri }}$ Banda.

Here the name must have changed previously from Kiri Bandiya to Kiri Banda. Banda is a Goigama name and Bandiya is a ;low caste' name. Name continues to be the same with initials RP Kiribanda.

Hapanpedige Sobana to Haputantri Plithage Sumith Samantha Somarathne.

Here an attempt has been made to retain the traditional initials HPS and consequently a new vasagama name 'Palithage' has been invented - Palitha is usually a first name, but here it has been used as a vasagama.

Horatal Pedige Chara to Hewa Patiranage Charlis.

Chara is a mutation of the Anglican name Charles, which is often used in villages as a first name for 'low' caste people. However, Charlis is an often-used name by the traditional low country Sinhalese. Some times Charlis is fully Anglicized to Charles to make it exceptional. Here the first name as well as the vasagama has been changed to make the name modern.

Family name changes by the 'low castes' show that the assumption of obvious Goigama family names was the predominant type, which accounted for $74 \%$ of the name changes reported in the newspaper notifications (Table III). Theacaste names were about $15 \%$ of the total newly assumed family names. Those who changed their traditional family names did not assume caste names other than Goigama, except in cases of regional importance. An example for this is the assumption of Karawa names in coastal districts.

\section{DISCUSSION AND CONCLUSION}

Although it is not quite clear as to whether these family name changes were obvious step towards changing caste status, when the whole family has changed the family name and assumed a family name of a different caste, it is possible to hypothesize that caste status has been changed. This type of name change accounted for about $34 \%$ of the total family name changes. However, in cases where individuals adopted a caste names and new family names, it is hard to say, without facts, that they aspired to change their caste status. The majority was concerned about changing over to a family name that would not jeopardies their personality and would enable them to 'socialize' in the wider society. They were all concerned about caste connotations of traditional 'low caste' name, for they have all changed their traditional family names.

Particularly interesting is the fact that a considerable proportion of name changes was of a caste type. They did not want to change over to Goigama names, as they were not concerned about changing the caste status. The individuals who changed their names to 'Goigama type'names are a large percentage of family name changes, and hence difficult to hypothesis that such individuals had completely severed their relationship with their family and kinsfolk in the villages, and assumed entirely new caste status. Although these individuals have changed their family names to look like those of the Goigama, they continue to be with the family and marry within the caste as seen in clear cut examples from villages. In some families of 'low caste' origin, sons and daughters have different high caste family names. Some families have Dissanayakes, Jayawardenes, Kumarathunges and Fonsekas as sisters and brothers. These concrete examples show those family name changes and assuming high caste names are not necessarily changing the caste status.

The family name changes by the Goigama shows that the majority of them did not intend to change their caste status, but assumed title names of radala Goigama, or opted to modernized their traditional names. These changes show that people who opted to change their names were more concerned with social and class status expressed in the name.

Overall, it showed that family names are considered a marker of social status. The significance of name as a status marker is seen among the Sinhalese than in any other ethnic group in the country. Individual mobility in the change social context may have established preconditions for name changes. Increased urbanization, colonization programs involving mass mobilization of people, educational opportunities and seeking jobs outside the native villages, problems associated with prospective marriages are some of the apparent background factors that may have precipitated the increase in name changes.

It is argued here that name changes are associated with achieving higher social status than with changing caste status. The name changes are also seen as an attempt by the individuals to naturalize name from being used as an identifier of caste. The change of family name can also be explained as an attempt by the individuals to minimize the effects of caste connotations in their dealing within the class society. Caste is thus loosing its expression at the level of the individual, but it does not necessarily mean that caste is loosing its expression as social groups, at regional levels or political arenas, where it is known to play a vital role. 


\section{ACKNOWLEDGEMENT}

The university of peradeniya provided found for this study (Grant No: RG/96/10/A) Ms.Ajntha peiris, Miss. Sujatha Mallawa Arachchi and Mr.Bandara collected the data. The Department of Archives grant permission to browse through the old newspapers. We thank all of them.

\section{REFERENCES}

[1] Leach,E.R. (1961) PulEliya, A village in Ceylon. Cambridge University Press, U.K.
[2] Obeysekere, G. (1967). Land tenure in village Ceylon. Cambridge University Press, U.K.

[3] Peiris, R. (1956). The Flexibility of caste principles in a Kandyan community.

\section{AUTHORS}

First Author - M.W. Amarasiri De Silva, Department of sociology, Faculty of Arts, University of Peradeniya.

Second Author - Shantha Wanninayake, Department of sociology, Faculty of Arts, University of Peradeniya. 